\title{
A biocultural approach to the use of natural resources in Northeast
}

\section{Brazil: A socioeconomic perspective}

\section{Nylber Augusto da Silva ${ }^{1}$ (D), Ângelo Giuseppe Chaves Alves ${ }^{2}$ (iD), Ulysses Paulino de Albuquerque ${ }^{3}$ (D) and Marcelo Alves Ramos ${ }^{4 *}$ (1)}

Received: September 30, 2018

Accepted: April 8, 2019

\section{ABSTRACT}

We employed a biocultural approach to understanding the dynamics of knowledge ans use of natural resources associated in immaterial aspects of culture. We investigated whether factors such as sex, income, age, religion, occupation and time of participation in cultural practice influence the richness of species known and used by members of Cavalo Marinho, expression of the popular culture of the Brazilian Northeast that brings together theater, music and dance. We recorded a total of 111 ethnospecies (95 plants and 16 animals), based on information obtained from 56 informants. There was a predominance of native plants and domestic animals in the knowledge of the participants in this cultural expression, although effective use is restricted to few species. Men had greater knowledge of the species than women, while people with greater schooling and income, and those whose occupation is related to agriculture, homecare and art, used more resources than other participant. The influence of socioeconomic factors on the knowledge and use of natural resources related to intangible aspects of culture differs, in some respects (schooling, gender and occupation), from that reported for the use of natural resources for subsistence purposes.

Keywords: biocultural approach, biocultural heritage, cultural practice, intracultural variation, knowledge and use, natural resources

\section{Introduction}

Biocultural heritage involves the set of knowledge, innovations and practices of indigenous and local communities that are collectively maintained and inextricably linked and shaped by the social-ecological context of the communities (Gavin et al. 2015). Research has shown that, especially in situations of environmental, economic and cultural changes, this heritage has been altered, generating the abandonment of cultural practices and the consequent loss of local knowledge over time (Gavin et al. 2015; Ladio \& Lozada 2003).
This effect has received attention in biocultural approaches, since this loss of knowledge has direct implications on the future use of natural resources (Ladio \& Lozada 2003; Albuquerque 2006). In this perspective, researchers have emphasized the importance of distinguishing "knowledge" from "current use" since a resource can be widely known among a group of people, although not necessarily used by all members (Ramos et al. 2008; Campos et al. 2015). This distinction has been contributing to elucidate issues that interfere with local knowledge as well as helping to determine whether knowledge and use of species are correlated or not (Campos et al. 2015).

1 Programa de Pós-graduação em Etnobiologia e Conservação da Natureza, Departamento de Biologia, Universidade Federal Rural de Pernambuco, 52171-900, Recife, PE, Brazil

2 Departamento de Biologia, Universidade Federal Rural de Pernambuco, 52171-900, Recife, PE, Brazil

3 Laboratório de Ecologia e Evolução de Sistemas Socioecológicos, Departamento de Botânica, Centro de Ciências Biológicas,

Universidade Federal de Pernambuco, 50670-901, Recife, PE, Brazil

4 Laboratório de Estudos Etnobiológicos, Universidade de Pernambuco, 55800-000, Nazaré da Mata, PE, Brazil

* Corresponding author: marcelo.alves@upe.br 
Among the various factors that may influence the knowledge and use of natural resources, age (CamouGuerrero et al. 2008; Lyon \& Hardesty 2014), gender (Albuquerque et al. 2011; Torres-Avilez et al. 2016), income (Medeiros et al. 2011), occupation (Silva et al. 2011), schooling (Saynes-Vásquez et al. 2013), and religion (Bhagwat et al. 2011; Sharma \& Pegu 2011) are commonly considered by researchers to understand the dynamics of knowledge and use of natural resources for various purposes.

Such approaches have helped to understand the social relations between the use and management of natural resources, as well as to develop methods for the conservation of natural resources, based on the knowledge patterns and current use of these resources (Beltrán-Rodríguez et al. 2014; López et al. 2015). These efforts have been directed towards cultural practices related to human subsistence, such as the use of resources for food (Campos et al. 2015), fuel (Ramos et al. 2008), medicine (Almeida et al. 2012), and wood (Ramos et al. 2015). However, there are no reports of cultural practices related to intangible aspects of culture such as festivals, dances, songs and rituals.

Researches that have described these expressions of culture highlighted the importance in understanding the relation of human groups with natural resources, since these cultural practices use and transmit information about the natural world in which its members are incorporated (Mekbib 2009; González et al. 2015). In the Brazilian Northeast, expressions of popular culture such as "Cavalo Marinho", which involves dance, music and poetry, represent well these cultural practices. It promotes the relationship of its members with the natural resources of local ecosystems as they make artifacts that are necessary for the cultural practice (Oliveira 1994; Alcântara 2014).

To understand the relation of human groups with natural resources, given the relevance of these immaterial aspects of culture, this study is a first approximation of "Cavalo Marinho" cultural practice, aiming to understand the dynamics of knowledge and use of the natural resources employed for its execution. We seek to answer the following questions: (a) What species are known and used as a resource in "Cavalo Marinho"? (b) Is the richness of species known and used by members influenced by socioeconomic factors such as gender, schooling, income, occupation, religion, and period of participation in the practice? We expect to find higher levels of knowledge and use of natural resources among the following members: (a) male individuals, because the insertion of women in the practice of "Cavalo Marinho" is recent. Studies carried out in other socialecological systems have reported that levels of knowledge and use of natural resources, when related to gender, are driven by their social role in the studied context (TorresAvilez et al. 2016); (b) those who have lower levels of schooling, because the members of this practice grew in a social context in which education is not a priority. The relationship between schooling, knowledge and use has been reported for other social-ecological systems (SaynesVásquez et al. 2013). According to Medeiros et al. (2011) higher levels of schooling, which is directly associated to occupation and income, promotes the inclusion of people into more qualified activities, leading to less contact with local ecosystem resources; (c) those that have low income, because the salaries related to agriculture are low, matching with the profile of the majority of the members of this practice. The inverse relationship between the income factor and the knowledge and use of resources is associated with the fact that people with low purchasing power often depend on natural resources to complement household activities, such as the use of fuel plants, leading to greater contact with natural resources (Ramos et al. 2008); (d) those that have activities related to the field, since a good part of the members of "Cavalo Marinho" are rural workers. Studies indicate that occupations in the field promote greater contact with natural resources and, therefore, higher levels of knowledge and use of resources (Medeiros et al. 2011); those who have more time to participate in the cultural practice, because they understand that this factor can better represent the accumulated experience of the members about the resources that are known and used in the practice than the age factor (Voeks \& Leony 2004); (f) among informants who adopt religions of African origin, considering that elements of these religions are present in "Cavalo Marinho" and that these religions promote a greater contact with natural resources (Alves et al. 2012).

\section{Brief characterization of "Cavalo Marinho" as Biocultural Heritage}

"Cavalo Marinho" is a popular singing and dancing theater that integrates the festivities of the Christmas festivals of cities in the states of Pernambuco and Paraíba (Grillo 2011; Queiroz 2014). There are reports that it originated in the nineteenth century, when Africans that were brought to work in sugar cane agriculture consolidated it in the senzalas of the engenhos (Benjamin 1999; Carneiro \& Filho 2010). Since then, this cultural expression has mixed dance, poetry and music to playfully portray the daily activities (present and past), real and imaginary, of rural workers (IPHAN 2014) (Fig. 1). From this perspective, the presentations deal with themes related to peasant life, sugar cane culture and elements of religious origin. Thus, the relationship between employer and employee, everyday conflicts, figures committed to social order and authority, sellers, street vendors, slaves, caboclos and figures of the popular imagination, mythical or necessary to the evolution of their plot, are dramatized (Carneiro \& Filho 2010).

Traditionally, this popular theater takes place between the months of December and January, when groups formed by 16 or 22 people gather to staging a Christmas Carol (Alto de Natal) in honor of the Divine Holy King of the East (IPHAN 


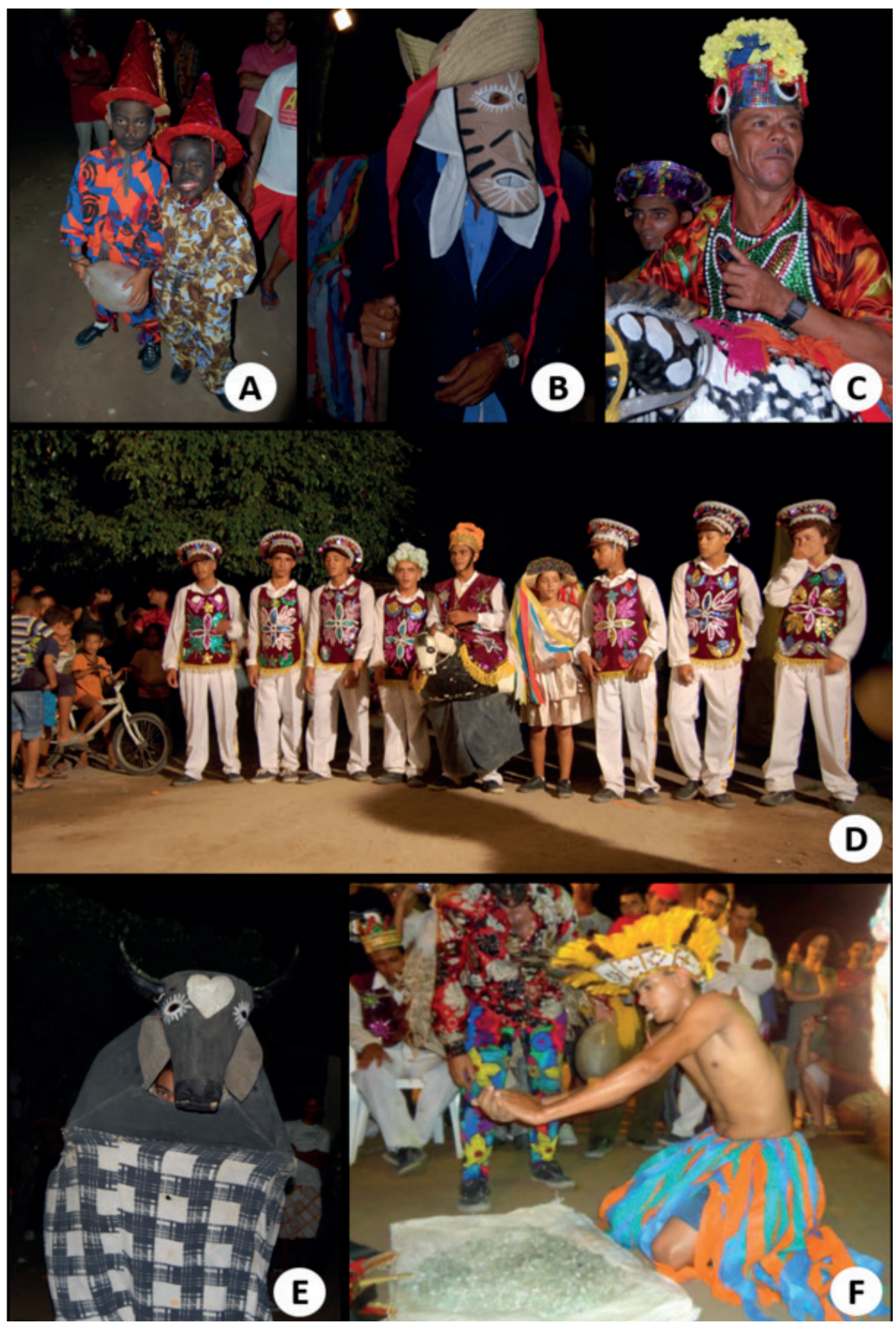

Figure 1. Illustration of a staging of "Cavalo Marinho", Pernambuco - Northeast - Brazil. A. Mateus and Bastião, characters that represent contracted slaves to take care of the staging. B. Soldado da Gurita, a masked character who represents order and social control. C. Captain, character who represents the boss / owner of the land / the lord /. The beginning of the plot of the Cavalo Marinho happens because he decides to organize a dance in honor of the Holy Kings of the East. D. Galantes, characters that appear in the ball for the Divine Holy Kings of the East moment of staging where the presence of popular Catholicism is remarkable.. E. Boi, an animal character of great importance for the Cavalo Marinho, considering its relevance in the context of sugarcane in the Northeast region. F. Caboclo de Urubá, a character who remits this cultural expression to the afro-indigenous traditions, making a clear connection with the religiousness of the Sacred Jurema. 
2014). Each presentation lasts an average of eight hours, and can last up to ten hours (Oliveira 2006). In this period, the members, mostly men of various ages (considering that the inclusion of women in this cultural practice is recent), incorporate different characters (about 70) that may be: (a) human beings with painted faces or wearing masks; (b) dolls, which represent human figures of disproportional size or; (c) animals, such as the ox, the jaguar, the donkey, the horse (Oliveira 2006). In addition, during the presentation, it is also shown: (a) several types of dances; (b) a rich musical repertoire executed by instruments made locally, such as rabeca, baje e ganzá, and also instruments acquired in local commerce, such as pandeiro (Fig. 2); (c) moments of praise to the Divine Holy King of the East, as a reference to the Catholic religion; and (d) the jurema cult (popular name given to the plant species Mimosa tenuiflora), afro-indigenous derived religion found in the Brazilian Northeast (Grillo 2011).

In order to maintain the structure and organization for the presentations, that is, to construct characters, to compose their clothes and make essential instruments for the staging, over the years the members of "Cavalo Marinho" have resorted to the use of plant and animal resources (Oliveira 1994; Alcântara 2014). The "ox bladder", for example, is used to compose the costume of some characters, as well as a musical instrument that supports the rhythm of the music accompanying the presentations (Fig. 2). Leather, also extracted from cattle and animals such as "goat", "sheep" and "cat", is widely used to make masks and musical instruments (Alcântara 2014). The resources obtained from plants, are more associated to the construction of the characters that make up the dance represented by animals such as ox, ema, jaguar and horse, confection of artifacts and the construction of musical instruments such as rabeca, baje, ganzá and pandeiro (Fig. 2). To make the rabeca, a type of rustic violin used in popular Brazilian festivals, for example, it is required the use of plant species that are typical of the Atlantic Forest (Oliveira 1994; Alcântara 2014).

After having experienced the violent and unjust context of slave society and resisting the socioeconomic changes of sugar cane agriculture, "Cavalo Marinho" adapted to the urban context, entered the digital age and influenced the contemporary artistic world (IPHAN 2014). Due to its sociocultural importance and because it is a tradition that corroborates the concept of intangible heritage, it was recognized in 2014 as Brazilian Intangible Heritage by IPHAN - National Historical and Artistic Heritage Institute (IPHAN 2014).

\section{Materials and methods}

\section{Study area}

The study was conducted with "Cavalo Marinho" groups, in the cities of Aliança, Araçoiaba, Camutanga, Condado, Itambé (State of Pernambuco) and Pedras de Fogo (State of Paraíba), Northeast Brazil (Fig. 3) (IBGE 2010). The cities selected for the study are distant approximately 110 $\mathrm{km}$ from Recife, capital of Pernambuco (IBGE 2010), and are located in the coastal strip of their respective states (Fig. 3). The predominant biome in the municipalities is composed of dense ombrophilous forest. However, the local landscape has been altered over the years by human activities. Deforestation is the main one, and it started in the sixteenth century with the arrival of the Portuguese colonizers to Pernambuco, initially for logging, later for livestock and sugar production (Trindade et al. 2008). Currently, environmentally transformed areas are used for commercial and subsistence agriculture, with sugarcane plantations representing the largest planted areas (Trindade et al. 2008). The Atlantic Forest Biome has been identified as a provider of sustenance for human populations that live in its surroundings, especially those with low purchasing power (Silva \& Andrade 2006; Medeiros et al. 2011; Almeida et al. 2012).

\section{Selection of participants}

In order to identify groups for the study, a preliminary survey was made on the existence of the active "Cavalo Marinho" groups, through consultation with the specialized literature (IPHAN 2014). From this effort, it was possible to identify a total of 12 groups, which were visited between July 2016 and February 2017 to present the research. Subsequently, in order to identify other groups, the technique of the snowball was applied, in which, at the end of each visit, the group leader was asked about the existence of other groups (see Albuquerque et al. 2014). Thus, the number of groups identified was increased to 14 , among which 10 groups accepted to participate in the study (Tab. 1).

In a second moment, to select people, a survey was made to identify the current participants of the ten groups of "Cavalo Marinho" selected in this research, considering the minimum age of 18 years. Thus, the head of each group was asked to list its members, totaling 73 people with the desired profile, of which 56 accepted to contribute to the study. All participants involved in the research signed the Informed Consent Term (ICT) following the requirements of the Research Ethics Committee of the National Health Council of Brazil, resolution no. 466/12. This project was authorized by the Research Ethics Committee of the University of Pernambuco (UPE) ( $n^{\circ}$ 52875615.8.0000.5207).

\section{Data Collection}

Individualized semi-structured interviews were conducted to obtain information for the study (see Albuquerque et al. 2014). Thus, information on the socioeconomic profile of the 56 participants (49 men and seven women, selected between July 2016 and January 

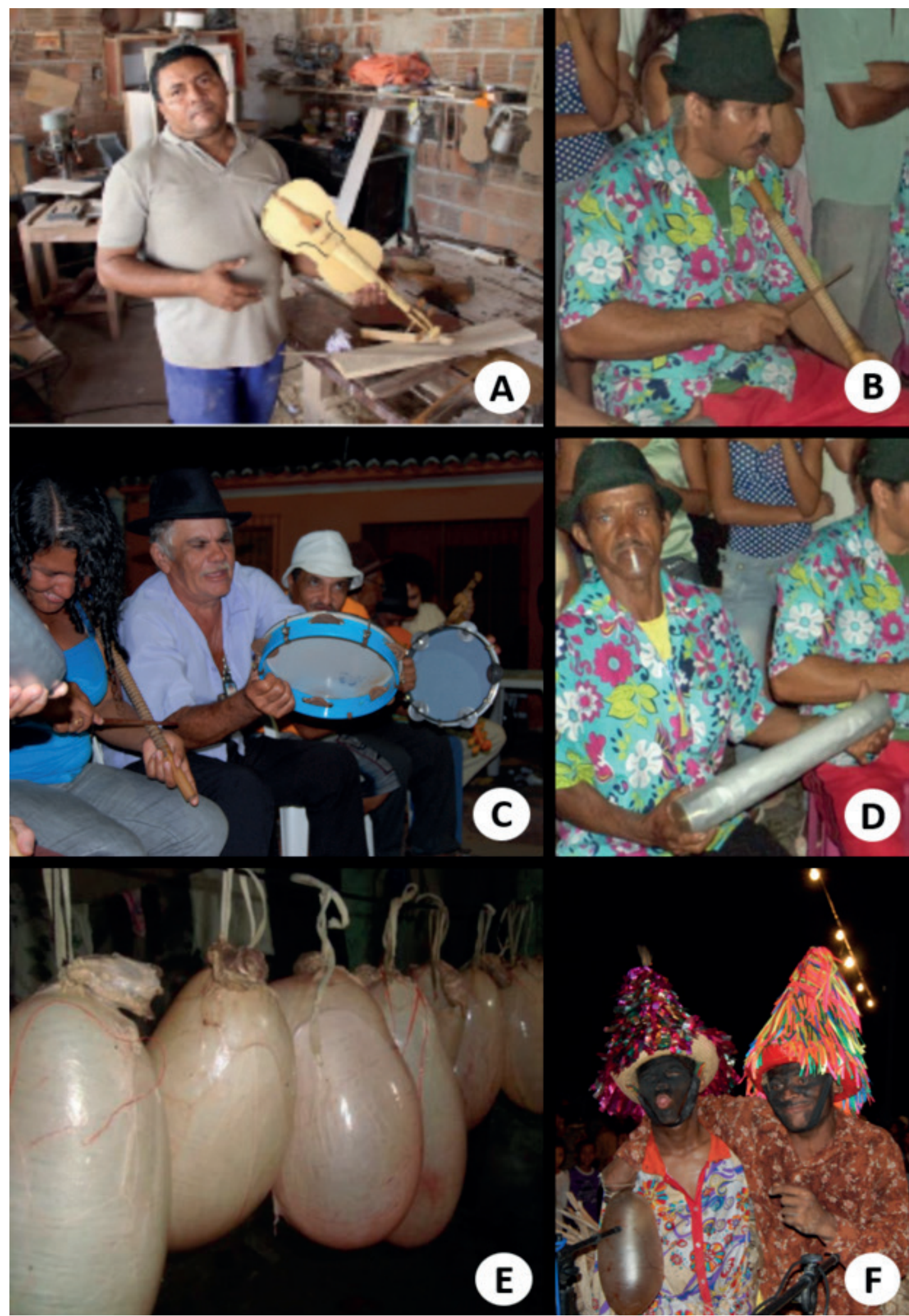

Figure 2. Representation of the musical instruments used in "Cavalo Marinho", Pernambuco - Northeast - Brazil. A. Rabeca or "rebeca", type of rustic, handmade violin, made by artisans of the Northeast region. B. Bage, type of reco-reco, made by the participant of the "Cavalo Marinho". It is made with Guadua weberbaueri (taboca), which is a species of Bambusa vulgaris (bamboo) thinner. C. Pandeiro, a percussion instrument consisting of an animal or synthetic skin stretched on a narrow rim which does not constitute a resonance box. D. Ganzá or "miner" instrument of african origin, very widespread in Brazil. E-F. Bladder, organ extracted from the "ox" that is used both as part of the dress of some characters of the "Cavalo Marinho" as a musical instrument. 
2017) was obtained regarding sex, schooling, income, occupation, religion and time of participation in the cultural expression. The information about the plants and animals that are used as resources by "Cavalo Marinho" groups was applied to the free-listing technique (see Albuquerque et al. 2014). At that moment, the interviewees were asked to answer the following questions: (a) Animals and/or plants have any use for "Cavalo Marinho"? (b) If yes, what use (s) does it have? (c) What animal (s) and plant (s) do you know for that purpose? (d) Among the animal (s) and/or plant (s) mentioned, do you use or have used any? If so, which ones?

In order to complement the information obtained in the free list, during the application of this technique, stimuli such as nonspecific prompting were used. With that the people were questioned: if they did not know any animal and/ or plant soon after the person affirmed not remembering

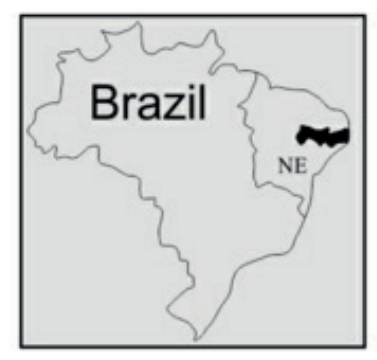

Convenções Cartográficas

Urban perimeter

- Study area

Urban perimeter of the study area

- National highway

- State highway

- State limit

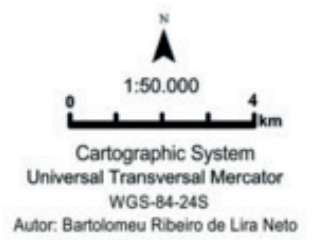

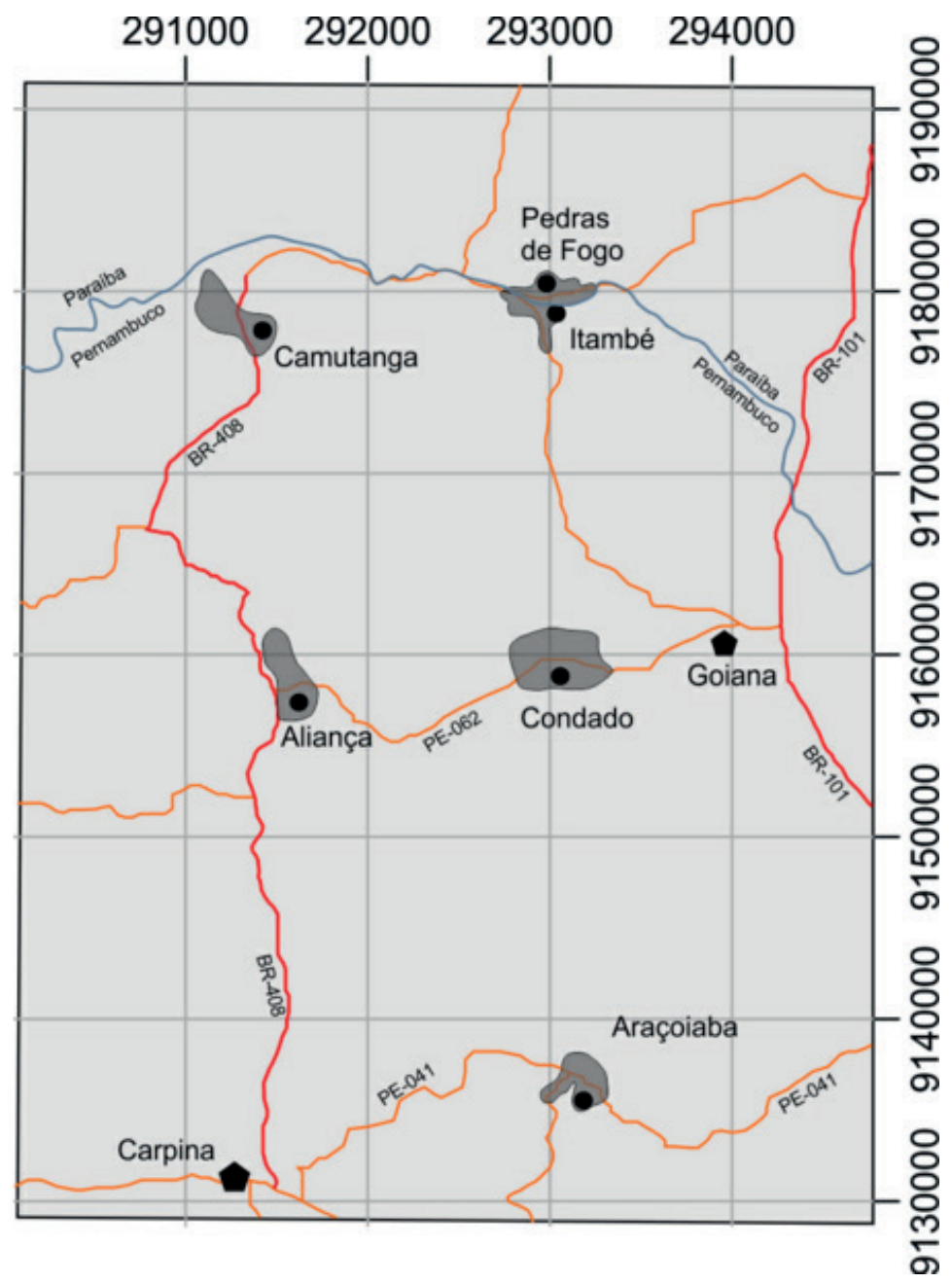

Figure 3. Map of the cities involved in the study.

Table 1. Characterization of the "Cavalo Marinho" groups involved in the study. M - Man; W - Woman.

\begin{tabular}{|c|c|c|c|c|c|c|}
\hline \multirow{2}{*}{\multicolumn{2}{|c|}{ State/ County }} & \multirow{2}{*}{ Group } & \multirow{2}{*}{ Year Foundation } & \multirow{2}{*}{ Members (age $\geq 18$ years) } & \multicolumn{2}{|c|}{ Interviewed } \\
\hline & & & & & M & $w$ \\
\hline \multirow{9}{*}{ Pernambuco } & \multirow{2}{*}{ Aliança } & Boi Pintado & 1993 & 12 & 7 & 2 \\
\hline & & Mestre Batista & 1956 & 5 & 5 & 0 \\
\hline & Araçoiaba & Boi Coroado & 1975 & 2 & 1 & 0 \\
\hline & Camutanga & Estrela do Oriente & 1973 & 3 & 1 & 0 \\
\hline & \multirow{3}{*}{ Condado } & Estrela Brilhante & 2004 & 12 & 9 & 1 \\
\hline & & Estrela de Ouro & 1979 & 11 & 10 & 1 \\
\hline & & Boi Brasileiro & 2000 & 10 & 7 & 3 \\
\hline & \multirow{2}{*}{ Itambé } & Boi Maneiro & 2012 & 4 & 2 & 0 \\
\hline & & Boi de Prata & 2006 & 3 & 1 & 0 \\
\hline \multirow[t]{2}{*}{ Paraíba } & Pedras de Fogo & Boi de Ouro & 1988 & 11 & 5 & 0 \\
\hline & & \multicolumn{2}{|c|}{ Total } & 73 & \multicolumn{2}{|c|}{56} \\
\hline
\end{tabular}


more elements; the new reading (reading back), where all the animals and plants cited by the informant were read again so that it was possible to add resources that the informant had forgotten; and the semantic cues, in which the participant was questioned about the existence of resources that are similar to those he has already mentioned (see Albuquerque et al. 2014).

In order to identify and collect the plants cited by the interviewees on the free list, the guided tour technique was used (see Albuquerque et al. 2014), in which an informant, recognized by others as a deep authority of plants used in "Cavalo Marinho", was selected to assist in the collection of plants. The identification of the collected botanical material was performed through the consultation of studies developed in the region and the assistance of specialists from the Agronomic Institute of Pernambuco (IPA), where the specimens are deposited.

The animals cited by the informants were recorded according to their citation. Species were identified based on (1) analyzes of individuals (or parts of the body) donated by the participants; (2) analysis of photographs of animals taken during interviews or by accompanying informants during their acquisition; and (3) tracking of vernacular names with the help of taxonomists who are familiar with local wildlife (Souto et al. 2018). The identification of the species was also facilitated by the use of specialized literature (Alves et al. 2011; 2012).

The plants identified were classified as: (a) native or exotic according to their biogeographic origin. We consider native species those that are endemic to the region of study and native to South America, and exotic species those that have extracontinental origin and are cultivated in the region and widely distributed as invasive and cosmopolitan tropical species; (b) arboreal, herbaceous shrub and liana according to their habit. The animals identified were classified according to their occurrence as: (a) wild and (b) domestic.

\section{Data Analysis}

The frequency of knowledge and use of the species cited in the interviews was calculated by dividing the number of people who reported knowing and/or using a given species by the total number of people interviewed. In order to verify the influence of socioeconomic factors (gender, schooling, income, occupation, religion and participation time in the cultural practice), independent variables on knowledge ( $\mathrm{n}^{\circ}$ of species cited as known) and use ( $\mathrm{n}^{\circ}$ of species cited as used), we applied generalized linear models (GLMs) followed by Poisson distribution. For this analysis, the independent variables gender, schooling, income, occupation and religion were categorized in absolute terms, except for the variable time of participation in the cultural practice, whose value used in the analysis was the value reported by the informants (Tab. 2). After the test, we selected the most explanatory model according to its degree of significance $(p<0.05)$. All analyzes were performed using the software $\mathrm{R}$ version 3.2.3 (R Development Core Team 2018).

\section{Results}

\section{Knowledge and use of species}

A total of 95 plants were cited by their popular name as a useful resource for "Cavalo Marinho" (Tab. 3). However, from this total only 36 plants were indicated as resources that are effectively used in the present day. We identified 63 species, distributed among 61 genera and 51 families, with emphasis on Lamiaceae (four spp.), Euphorbiaceae (three spp.), Fabaceae (three spp.), Moraceae (three spp.), Myrtaceae (three spp.) and Sapindaceae (three spp.) (Tab. 3). Among the plants identified, 44 species are native and 19 exotic, with predominance of arboreal habit (69.84\%),

Table 2. Distribution of the socioeconomic profile of the participants by category, number of people and percentage.

\begin{tabular}{|c|c|c|c|}
\hline Explanatory Variable & Category & $\mathrm{N}^{\circ}$ of People & $(\%)$ \\
\hline \multirow{2}{*}{ Gender } & Man & 49 & 87.50 \\
\hline & Woman & 7 & 12.50 \\
\hline \multirow{4}{*}{ Education } & Non-literate & 5 & 8.93 \\
\hline & Elementary School & 19 & 33.93 \\
\hline & High school & 30 & 53.57 \\
\hline & Higher education & 2 & 3.57 \\
\hline \multirow{4}{*}{ Occupation } & provision of services & 23 & 41.08 \\
\hline & agriculture & 6 & 10.71 \\
\hline & Art & 20 & 35.71 \\
\hline & home & 7 & 12.50 \\
\hline \multirow{3}{*}{ Income } & $<1$ minimum wage & 31 & 55.35 \\
\hline & 1 até 2 minimum wages & 23 & 41.07 \\
\hline & $>2$ até 3 minimum wages & 2 & 3.57 \\
\hline \multirow{3}{*}{ Religion } & Without religion & 13 & 23.22 \\
\hline & Christian religion & 33 & 58.92 \\
\hline & African Matrix Religion & 10 & 17.86 \\
\hline Time of participation in this cultural practice & Time reported by the participant & 56 & 100 \\
\hline
\end{tabular}


followed by hebaceous (22.22\%), liana (4.7\%) and shrub (3.1\%) (Tab. 3).

Smilax rotundifolia (japecanga) (60.71\%), Guadua weberbaueri (taboca) (58.93\%) and Bambusa vulgaris (bamboo) (41.07\%) stand out among the best known plants for "Cavalo Marinho" groups that participated in the study (Tab. 3). These species also prevailed among the most used by the groups, along with Erythrina velutina Wilid. (Mulungu) (14.28\%) and Genipa americana L. (Genipapo) $(10.71 \%)$, respectively, presenting the following frequencies of citations: $23.21 \%, 30.36 \%$ and $10.71 \%$ (Tab. 3).

In addition to the plants, 16 animals referred to by their popular name were also registered as useful resources for "Cavalo Marinho" (Tab. 4), of which only three were indicated as a resource effectively used. It was possible to identify 11 animals from the 16 ethnoespecies mentioned by the informants, of which nine were domesticated and only two were wild (Tab. 4). These species are distributed among 10 genera and 8 families, with emphasis on Bovidae (three spp.) and Felidae (two spp.). Species such as "cattle" (Bos taurus) (known by $85.71 \%$ and used by $23.21 \%$ of respondents), "goat" (Capra hircus) $(C=42.86 \% ; \mathrm{U}=7,14 \%)$ and "horse" (Equus caballus) $(\mathrm{C}=25.00 \%, \mathrm{U}=3.57 \%)$ presented a high frequency of citation as both known and used species (Tab. 4).

There were 30 uses attributed to the plants and 13 uses attributed to the animals cited as resources associated with "Cavalo Marinho". These were distributed among five categories of use that can be seen in Table 5. When related

Table 3. Species of plants cited as known and used by participants of the "Cavalo Marinho" groups. Ad - Adornment; Ch - Characters; Eq - Equipment; MI - Musical instrument; SC - Spiritual Cleansing.

\begin{tabular}{|c|c|c|c|c|c|c|c|}
\hline \multicolumn{8}{|c|}{ PLANTS } \\
\hline \multirow[t]{2}{*}{ Family - Species } & \multirow{2}{*}{ Popular Name } & \multicolumn{2}{|c|}{$\begin{array}{l}\text { Frequency of } \\
\text { Citation (\%) }\end{array}$} & \multirow[t]{2}{*}{ Habit } & \multirow[t]{2}{*}{ Occurrence } & \multirow[t]{2}{*}{ Origin } & \multirow{2}{*}{$\begin{array}{l}\text { Indication } \\
\text { of use }\end{array}$} \\
\hline & & Known & Used & & & & \\
\hline \multicolumn{8}{|c|}{ Anacardiaceae } \\
\hline Anacardium occidentale L. & Cajueiro & 1.78 & 0 & Arboreal & Domestic & Native & MI \\
\hline Tapirira guianensis Aubl. & Cipaúba & 1.78 & 0 & Arboreal & Wild & Native & $\mathrm{Eq}, \mathrm{Ch}$ \\
\hline Tapirira guianensis Aubl. & Cupiúba & 1.78 & 0 & Arboreal & Wild & Native & $\mathrm{Eq}, \mathrm{Ch}$ \\
\hline \multicolumn{8}{|c|}{ Araliaceae } \\
\hline Schefflera morototoni (Aubl.) Maguire, Steyerm. \& Frodin & Sambaquim & 1.78 & 0 & Arboreal & Wild & Native & $\mathrm{Ch}$ \\
\hline \multicolumn{8}{|c|}{ Bignoniaceae } \\
\hline Handroanthus ochaceus (Cham.) Mattos & Pau d'arco & 10.71 & 3.57 & Arboreal & Wild & Native & $\mathrm{Ad}, \mathrm{Eq}, \mathrm{MI}, \mathrm{Ch}$ \\
\hline Lundia cordata (Vell.) DC. & Cipó de Cesto & 23.21 & 5.36 & Liana & Wild & Native & Ad, $\mathrm{Ch}$ \\
\hline \multicolumn{8}{|c|}{ Boraginaceae } \\
\hline Cordia trichotoma (Vel.) Arráb. Ex. Steud. & Louro & 1.78 & 5.36 & Arboreal & Wild & Native & Eq, MI, SC, Ch \\
\hline Cordia trichotoma (Vel.) Arráb. Ex. Steud. & Freijó & 5.36 & 5.36 & Arboreal & Wild & Native & Eq, MI, SC, Ch \\
\hline \multicolumn{8}{|c|}{ Bromeliaceae } \\
\hline Aechmea aquilega (Salisb.) Griseb. & Gravatá & 1.78 & 0 & Herbaceous & Wild & Native & MI \\
\hline \multicolumn{8}{|c|}{ Cactaceae } \\
\hline Cereus jamacaru DC. & Cardeiro & 7.14 & 1.78 & Arboreal & Wild & Native & MI \\
\hline \multicolumn{8}{|c|}{ Cecropiaceae } \\
\hline Cecropia palmata Willd. & Embaúba & 1.78 & 0 & Arboreal & Wild & Native & Ad, MI \\
\hline \multicolumn{8}{|c|}{ Combretaceae } \\
\hline Combretum leprossum Mart. & Mufumbo & 8.93 & 0 & Arboreal & Wild & Native & $\mathrm{Ad}, \mathrm{Ch}$ \\
\hline \multicolumn{8}{|c|}{ Crysobalanaceae } \\
\hline Hirtella racemosa Lam. & Cabo Curso & 1.78 & 0 & Arboreal & Wild & Native & Eq, MI \\
\hline Hirtella racemosa Lam. & Pau Brasil & 3.57 & 1.78 & Arboreal & Wild & Native & $\mathrm{Eq}, \mathrm{MI}$ \\
\hline \multicolumn{8}{|c|}{ Dilleniaceae } \\
\hline Davilla kunthii A.St.-Hil. & Cipó de Fogo & 37.50 & 3.57 & Bushy & Wild & Native & $\mathrm{Ad}, \mathrm{Ch}$ \\
\hline \multicolumn{8}{|c|}{ Equisetaceae } \\
\hline Equisetum cf. giganteum L. & Cavalinha & 1.78 & 0 & Herbaceous & Wild & Exotic & MI \\
\hline \multicolumn{8}{|c|}{ Erythroxylaceae } \\
\hline Erythroxylum suberosum A. St.-Hil. & Cocão & 1.78 & 0 & Arboreal & Wild & Native & $\mathrm{Ch}$ \\
\hline \multicolumn{8}{|c|}{ Euphorbiaceae } \\
\hline Croton blanchetianus Baill. & Marmeleiro & 1.78 & 0 & Arboreal & Wild & Native & $\mathrm{Ch}$ \\
\hline Jatropha gossypiifolia L. & Pião-Roxo & 1.78 & 1.78 & Herbaceous & Domestic & Exotic & SC \\
\hline Sapium glandulatum (Vell.) Pax & Burra Leiteira & 1.78 & 0 & Arboreal & Wild & Native & MI \\
\hline \multicolumn{8}{|c|}{ Fabaceae } \\
\hline Dioclea virgata (Rich.) Amshoff & Cipó de Macaco & 1.78 & 0 & Liana & Wild & Native & Ad \\
\hline Enterolobium contortisiliquum (Vell.) Morong. & Tambor & 7.14 & 1.78 & Arboreal & Wild & Native & $\mathrm{MI}, \mathrm{Ch}$ \\
\hline
\end{tabular}


Table 3. Cont.

\begin{tabular}{|c|c|c|c|c|c|c|c|}
\hline \multicolumn{8}{|c|}{ PLANTS } \\
\hline \multirow[t]{2}{*}{ Family - Species (Scientific name) } & \multirow[t]{2}{*}{ Popular Name } & \multicolumn{2}{|c|}{$\begin{array}{l}\text { Frequency of } \\
\text { Citation }(\%)\end{array}$} & \multirow[t]{2}{*}{ Habit } & \multirow[t]{2}{*}{ Occurrence } & \multirow[t]{2}{*}{ Origin } & \multirow{2}{*}{$\begin{array}{c}\text { Indication } \\
\text { of use }\end{array}$} \\
\hline & & Known & Used & & & & \\
\hline Rhynchosia phaseoloides (Sw.) DC. & Olho de Pombo & 5.36 & 1.78 & Herbaceous & Wild & Exotic & MI \\
\hline \multicolumn{8}{|c|}{ Fabaceae-Caesalpinoideae } \\
\hline Apuleia leiocarpa (Vogel) J. F. Macbr. & Jitaí & 1.78 & 0 & Arboreal & Wild & Native & $\mathrm{Eq}$ \\
\hline \multicolumn{8}{|c|}{ Fabaceae-Faboideae } \\
\hline Pithecellobium saman var. acutifolium Benth. & Burdão-de-velho & 3.57 & 0 & Arboreal & Wild & Native & Eq, MI \\
\hline \multicolumn{8}{|c|}{ Fabaceae-Mimosoideae } \\
\hline Stryphnodendron pulcherrimum (Willd.) Hochr. & Comundongo & 1.78 & 1.78 & Arboreal & Wild & Native & Ad, Ch \\
\hline \multicolumn{8}{|c|}{ Hernadiaceae } \\
\hline Sparattantheliu botucudorum Mart. & Malva Rosa & 1.78 & 0 & Arboreal & Wild & Native & SC \\
\hline \multicolumn{8}{|c|}{ Lamiaceae } \\
\hline Lavandula spica Cav. & Alfazema & 3.57 & 3.57 & Herbaceous & Domestic & Exotic & SC \\
\hline Mentha villosa Huds. & Hortelã Miuda & 1.78 & 0 & Herbaceous & Domestic & Exotic & SC \\
\hline Ocimum basilicum L. & Manjericão & 1.78 & 0 & Herbaceous & Domestic & Exotic & SC \\
\hline Rosmarinus officinalis L. & Alecrim & 1.78 & 0 & Herbaceous & Domestic & Exotic & SC \\
\hline \multicolumn{8}{|c|}{ Lauraceae } \\
\hline Cassytha filiformis L. & Cipó Canela & 7.14 & 0 & Bushy & Wild & Native & $\mathrm{Ad}, \mathrm{Ch}$ \\
\hline Nectandra cuspidata (Ness \& Mart.) Ness & Canela & 1.78 & 0 & Arboreal & Wild & Native & Ad \\
\hline \multicolumn{8}{|c|}{ Lecythidaceae } \\
\hline Eschweilera ovata (Cambess.) Miers & Imbiriba & 1.78 & 0 & Arboreal & Wild & Native & $\mathrm{Ad}, \mathrm{MI}, \mathrm{Ch}$ \\
\hline Gustavia augusta L. & Japaranduba & 5.36 & 0 & Arboreal & Wild & Native & $\mathrm{Ad}, \mathrm{Ch}$ \\
\hline Gustavia augusta L. & Cipó Pau & 1.78 & 1.78 & Arboreal & Wild & Native & $\mathrm{Ad}, \mathrm{Ch}$ \\
\hline \multicolumn{8}{|c|}{ Leguminosae } \\
\hline Hymenaea courbaril L. & Jatobá & 3.57 & 0 & Arboreal & Wild & Native & Ad, MI \\
\hline \multicolumn{8}{|c|}{ Leguminosae - Caesalpiniaceae } \\
\hline Crotalaria retusa $\mathrm{L}$. & Xique-xique & 1.78 & 0 & Bushy & Wild & Exotic & MI \\
\hline \multicolumn{8}{|c|}{ Leguminosae - Caesalpinoideae } \\
\hline Caesalpinia ferrea Mart. ex Tul. & Jucá & 1.78 & 0 & Arboreal & Wild & Native & $\mathrm{Eq}, \mathrm{Ch}$ \\
\hline Caesalpinia ferrea Mart. ex Tul. & Pau Ferro & 1.78 & 0 & Arboreal & Wild & Native & $\mathrm{Eq}, \mathrm{Ch}$ \\
\hline & eguminosae - Mim & oidade & & & & & \\
\hline Parkia pendula (Willd.) Benth. ex Walp & Visgueiro & 1.78 & 0 & Arboreal & Wild & Native & MI \\
\hline & guminosae - Papil & noideae & & & & & \\
\hline Bowdichia virgilioides Kunth & Sucupira & 10.71 & 3.57 & Arboreal & Wild & Native & $\mathrm{Ad}, \mathrm{Eq}, \mathrm{Ch}$ \\
\hline Erythrina velutina Wilid. & Mulungu & 35.71 & 14.28 & Arboreal & Wild & Native & Ad, MI, Ch \\
\hline & Malvaceae & & & & & & \\
\hline Guazuma ulmifolia Lam. & Mutamba & 5.36 & 1.78 & Arboreal & Wild & Native & MI, Ch \\
\hline & Meliaceae & & & & & & \\
\hline Cedrela odorata L. & Cedro & 14.28 & 3.57 & Arboreal & Wild & Native & $\mathrm{MI}, \mathrm{Ch}$ \\
\hline & Mimosacea & & & & & & \\
\hline Inga edulis Mart. & Ingá & 1.78 & 0 & Arboreal & Wild & Native & MI \\
\hline Plathymenia foliolosa Benth. & Amarelo & 3.57 & 0 & Arboreal & Wild & Native & Eq, MI \\
\hline & Moraceae & & & & & & \\
\hline Artocarpus communis Forst & Fruta pão & 1.78 & 0 & Arboreal & Domestic & Exotic & MI \\
\hline Artocarpus heterophyllus Lam. & Jaqueira & 8.93 & 0 & Arboreal & Domestic & Exotic & MI, Ch \\
\hline Brosimum discolor Schott & Quiri & 21.43 & 7.14 & Arboreal & Wild & Native & Ad, MI, Ch \\
\hline & Musaceae & & & & & & \\
\hline Musa paradisiaca L. & Bananeira & 14.29 & 0 & Arboreal & Domestic & Exotic & Ad \\
\hline & Myrtaceae & & & & & & \\
\hline Eucalyptus citriodora Hook. & Eucalipto & 3.57 & 0 & Arboreal & Domestic & Exotic & Ad, SC \\
\hline Psidium guajava L. & Goiaba & 3.57 & 0 & Arboreal & Domestic & Native & Ad, SC \\
\hline Syzygium aromaticum Merr. \& L.M. Perry & Cravo & 1.78 & 0 & Arboreal & Domestic & Exotic & MI \\
\hline & Phytolaccace & & & & & & \\
\hline Petiveria alliacea $\mathrm{L}$. & Tipi & 3.57 & 1.78 & Herbaceous & Wild & Native & SC \\
\hline
\end{tabular}


Table 3. Cont.

\begin{tabular}{|c|c|c|c|c|c|c|c|}
\hline \multicolumn{8}{|c|}{ PLANTS } \\
\hline \multirow[t]{2}{*}{ Family - Species (Scientific name) } & \multirow[t]{2}{*}{ Popular Name } & \multicolumn{2}{|c|}{$\begin{array}{l}\text { Frequency of } \\
\text { Citation }(\%)\end{array}$} & \multirow[t]{2}{*}{ Habit } & \multirow[t]{2}{*}{ Occurrence } & \multirow[t]{2}{*}{ Origin } & \multirow{2}{*}{$\begin{array}{l}\text { Indication } \\
\text { of use }\end{array}$} \\
\hline & & Known & Used & & & & \\
\hline \multicolumn{8}{|c|}{ Poaceae } \\
\hline Bambusa vulgaris Schrad. ex J. C. Wendl. & Bambu & 41.07 & 10.71 & Arboreal & Domestic & Exotic & Ad, MI, Ch \\
\hline Guadua weberbaueri Pilger & Taboca & 58.93 & 30.36 & Arboreal & Domestic & Exotic & $\mathrm{Ad}, \mathrm{MI}, \mathrm{Ch}$ \\
\hline \multicolumn{8}{|c|}{ Rubiaceae } \\
\hline Genipa americana L. & Genipapo & 37.50 & 10.71 & Arboreal & Domestic & Native & $\mathrm{Ad}, \mathrm{Eq}, \mathrm{MI}, \mathrm{Ch}$ \\
\hline \multicolumn{8}{|c|}{ Rutaceae } \\
\hline Ruta graveolens $\mathrm{L}$. & Arruda & 3.57 & 3.57 & Herbaceous & Domestic & Exotic & SC \\
\hline \multicolumn{8}{|c|}{ Sapindaceae } \\
\hline Cardiospermum halicacabum L. & Cipó de Vaqueiro & 3.57 & 0 & Herbaceous & Wild & Native & Ad \\
\hline Serjania paucidentata DC. & Cipó de Cururu & 1.78 & 0 & Herbaceous & Wild & Native & $\mathrm{Ch}$ \\
\hline Cupania impressinervia Acev. Rodr. & Caboatã & 1.78 & 0 & Arboreal & Wild & Native & $\mathrm{Ch}$ \\
\hline \multicolumn{8}{|c|}{ Sapotaceae } \\
\hline Chrysophyllum rufum Mart. & Maçaranduba & 1.78 & 0 & Arboreal & Wild & Native & Ad \\
\hline \multicolumn{8}{|c|}{ Simaroubaceae } \\
\hline Simarouba amara Aubl. & Praíba & 10.71 & 5.36 & Arboreal & Wild & Native & Eq, MI \\
\hline \multicolumn{8}{|c|}{ Smilacaceae } \\
\hline Smilax rotundifolia L. & Cipó Japecanga & 60.71 & 23.21 & Herbaceous & Wild & Native & $\mathrm{Ad}, \mathrm{Ch}$ \\
\hline \multicolumn{8}{|c|}{ Tiliaceae } \\
\hline Luehea ochrophylla Mart. & Pereiro & 1.78 & 0 & Arboreal & Wild & Native & Ad, MI \\
\hline \multicolumn{8}{|c|}{ Verbenaceae } \\
\hline Vitex agnus-castus L & Liamba & 3.57 & 1.78 & Arboreal & Domestic & Exotic & SC \\
\hline \multicolumn{8}{|c|}{ Zingiberaceae } \\
\hline Alpinia zerumbet (Pers.) B.L. Burtt. \& R.M. Sm. & Colônia & 3.57 & 1.78 & Herbaceous & Domestic & Exotic & SC \\
\hline & Undetermined & & & & & & \\
\hline Undetermined 01 & Cipó Buji & 1.78 & 0 & Herbaceous & - & - & $\mathrm{Ad}, \mathrm{Ch}$ \\
\hline Undetermined 02 & Cipó de Paraqueda & 1.78 & 0 & Herbaceous & - & - & Ad \\
\hline Undetermined 03 & Cipó Rabo de Rato & 1.78 & 0 & Herbaceous & - & - & $\mathrm{Ch}$ \\
\hline Undetermined 04 & Cubaçu & 1.78 & 0 & Arboreal & - & - & Ad \\
\hline Undetermined 05 & Cubatã & 1.78 & 0 & Arboreal & - & - & Ad \\
\hline Undetermined 06 & Diquiri & 1.78 & 0 & Herbaceous & - & - & Ad \\
\hline Undetermined 07 & Esconta & 1.78 & 0 & Herbaceous & - & - & Ad \\
\hline Undetermined 08 & Imbuia & 5.36 & 3.57 & Arboreal & - & - & MI \\
\hline Undetermined 09 & Imburana & 1.78 & 0 & Arboreal & - & - & MI \\
\hline Undetermined 10 & Imburana de Cambão & 1.78 & 0 & Arboreal & - & - & MI \\
\hline Undetermined 11 & Jacarandá & 7.14 & 1.78 & Arboreal & - & - & $\mathrm{Ad}, \mathrm{Eq}, \mathrm{MI}$ \\
\hline Undetermined 12 & Louro faia & 1.78 & 0 & Arboreal & - & - & MI \\
\hline Undetermined 13 & Louro Vinhatico & 1.78 & 0 & Arboreal & - & - & MI \\
\hline Undetermined 14 & Macacaúba & 1.78 & 0 & Arboreal & - & - & MI \\
\hline Undetermined 15 & Mógno & 1.78 & 1.78 & Arboreal & - & - & MI \\
\hline Undetermined 16 & Muiracatiara & 1.78 & 0 & Arboreal & - & - & MI \\
\hline Undetermined 17 & Oliveira & 1.78 & 0 & Arboreal & - & - & SC \\
\hline Undetermined 18 & Pinho & 8.93 & 0 & Arboreal & - & - & MI \\
\hline Undetermined 19 & Pinho de Viga & 1.78 & 0 & Arboreal & - & - & MI \\
\hline Undetermined 20 & Pipiri & 3.57 & 1.78 & Bushy & - & - & MI \\
\hline Undetermined 21 & Piriquiti & 10.71 & 5.36 & Herbaceous & - & - & MI \\
\hline Undetermined 22 & Roxinho & 8.93 & 1.78 & Arboreal & - & - & Ad, MI \\
\hline Undetermined 23 & Samambaia & 3.57 & 1.78 & Herbaceous & - & - & $\mathrm{Ch}$ \\
\hline Undetermined 24 & Benjoim & 1.78 & 1.78 & Arboreal & - & - & $\mathrm{SC}$ \\
\hline Undetermined 25 & Cana Brava & 1.78 & 1.78 & Bushy & - & - & Ad \\
\hline Undetermined 26 & Cana da Índia & 1.78 & 0 & Bushy & - & - & MI \\
\hline Undetermined 27 & Cana Fischi & 1.78 & 0 & Bushy & - & - & MI \\
\hline
\end{tabular}


to plants, the category of musical instruments presented the largest number of ethnoespecies reported by the informants, whereas for animals, these numbers were more expressive in the costumes use category (Tab. 5).

\section{Influence of socioeconomic factors on species knowledge and use}

The Generalized Linear Model (GLM) showed that the socioeconomic variables gender, schooling, income and occupation, significantly $(p<0.05)$ influenced the levels of knowledge of informants (Tab. 6). Male informants with higher levels of education (higher level) and income (> 1 minimum wage) presented greater knowledge $(p<0.001)$ of species in the cultural practice. Similarly, people who develop artistic activities and those related to homecare also presented greater knowledge about the species (Tab. 6).

Regarding the use of resources, the generalized linear model (GLM) showed that the socioeconomic variables of schooling, income, occupation and length of participation in cultural practice significantly $(p<0.05)$ influenced levels of resource use by the informants (Tab. 7). In this sense, the number of species used increases according to the educational level of the informant. We also found significant levels $(p<0.05)$ of resource use among people who earn more than two minimum wages, who develop activities related to agriculture, art and home, and those that have more time available to participate in the cultural practice (Tab. 7).

\section{Discussion}

\section{Knowledge and use of species}

We found that the participants of the studied groups know more natural resources than they actually use. The differences between the number of species known and effectively used have also been reported by researchers who investigated the relationship of human groups with natural resources for other purposes (Nascimento et al. 2013), and it seems to be related to different factors.

Campos et al. (2015), for example, have observed that these differences can be influenced by local preferences of the population. Associated with this, it has also been observed that other factors also influence the dynamic "knowledge" and "effective use" of resources. For example, the availability of the resource in the environment, since some species are more used in detriment to others because they are easily found (Nascimento et al. 2016), and the access regime of the populations to the resources in the environment (Ramos et al. 2015), since natural resources can occur in common or private areas.

Table 4. Species of animals cited as known and used by participants of the "Cavalo Marinho" groups. Ad = Adornment; $\mathrm{Ch}=\mathrm{Characters;}$ $\mathrm{Eq}=$ Equipment; $\mathrm{MI}=$ Musical instrument.

\begin{tabular}{|c|c|c|c|c|c|}
\hline \multicolumn{6}{|c|}{ ANIMALS } \\
\hline \multirow{2}{*}{ Family - Species (Scientific name) } & \multirow{2}{*}{ Popular Name } & \multicolumn{2}{|c|}{ Frequency of Citation (\%) } & \multirow{2}{*}{ Origin } & \multirow{2}{*}{ Indication of use } \\
\hline & & Known & Used & & \\
\hline \multicolumn{6}{|c|}{ Bovidae } \\
\hline Bos taurus Linnaeus, 1758 & Boi & 85.71 & 23.21 & Domestic & Ad, Ch, MI \\
\hline Capra hircus Linnaeus, 1758 & Bode & 42.86 & 7.14 & Domestic & $\mathrm{Ad}, \mathrm{Ch}$ \\
\hline Ovis aries (Linnaeus, 1758) & Carneiro & 5.36 & 0 & Domestic & $\mathrm{Ad}, \mathrm{Ch}$ \\
\hline \multicolumn{6}{|c|}{ Caviidae } \\
\hline Equus caballus (Linnaeus, 1758) & Cavalo & 25.00 & 3.57 & Domestic & Ad, Ch, MI \\
\hline \multicolumn{6}{|c|}{ Equidae } \\
\hline Equus asinus Linnaeus, 1758 & Jumento & 1.78 & 0 & Domestic & Ad, $\mathrm{Ch}$ \\
\hline \multicolumn{6}{|c|}{ Erethizontidae } \\
\hline Coendou prehensilis (Linnaeus, 1758) & Coandú & 3.57 & 0 & wild & MI \\
\hline \multicolumn{6}{|c|}{ Felidae } \\
\hline Cerdocyon thous (Linnaeus, 1766) & Raposa & 1.78 & 0 & wild & Ad, MI \\
\hline Felis catus Linnaeus, 1758, 1775 & Gato & 1.78 & 0 & Domestic & Ad, MI \\
\hline \multicolumn{6}{|c|}{ Meleagrididae } \\
\hline Meleagris gallopavo Linnaeus, 1758 & Peru & 5.36 & 0 & Domestic & Ad, Ch, MI \\
\hline \multicolumn{6}{|c|}{ Rheidae } \\
\hline Rhea americana (Linnaeus, 1758) & Ema & 1.78 & 0 & Domestic & $\mathrm{Ad}, \mathrm{Ch}$ \\
\hline \multicolumn{6}{|c|}{ Tinamidae } \\
\hline Pavo cristatus Linnaeus, 1758 & Pavão & 3.57 & 0 & Domestic & $\mathrm{Ad}, \mathrm{Ch}$ \\
\hline \multicolumn{6}{|c|}{ Undetermined } \\
\hline Undetermined 28 & Burro & 5.36 & 0 & Domestic & $\mathrm{Ch}$ \\
\hline Undetermined 29 & Cobra & 1.78 & 0 & wild & MI \\
\hline Undetermined 30 & Guará & 1.78 & 0 & wild & Ad \\
\hline Undetermined 31 & Onça & 1.78 & 0 & wild & $\mathrm{Ch}$ \\
\hline Undetermined 32 & Puma & 1.78 & 0 & wild & Ad \\
\hline
\end{tabular}


Table 5. Characterization and description of the local use, in which the plants and animals are employed, based on the denomination of the participants of the "Cavalo Marinho".

\begin{tabular}{|c|c|c|c|c|}
\hline \multirow{2}{*}{ Category } & \multirow{2}{*}{ Description } & \multicolumn{3}{|c|}{ Quantity } \\
\hline & & Uses & Plants & Animals \\
\hline Adornment & $\begin{array}{l}\text { - When plants and/or animals are intended for the construction of objects, such as } \\
\text { necklaces, hats, ornaments, masks, among others, used to compose the image of the } \\
\text { members in cultural expression. }\end{array}$ & 14 & 35 & 8 \\
\hline Characters & $\begin{array}{l}\text { - When plants and/or animals are intended for the construction of non-human charac- } \\
\text { ters, such as animals and figures of the popular imagination, who present themselves } \\
\text { at some moments in the theater. }\end{array}$ & 11 & 32 & 6 \\
\hline Musical instrument & $\begin{array}{c}\text { - When plants and/or animals are used to make musical instruments, such as rabeca, } \\
\text { baje, ganzá, bexiga and others that are used to accompany the songs during the group } \\
\text { presentations. }\end{array}$ & 6 & 46 & 7 \\
\hline Equipment & $\begin{array}{l}\text { - When plants and/or animals are intended for the construction of objects, such as the } \\
\text { bench and the stilt, which serve as a structure for the presentation of groups and some } \\
\text { of their characters. }\end{array}$ & 2 & 13 & 0 \\
\hline Spiritual cleansing & $\begin{array}{l}\text { - When the use of plants and/or animals are intended for the preparation of solutions } \\
\text { used as baths, the effect of which produces spiritual protection and the removal of evil } \\
\text { eye before the presentations. }\end{array}$ & 2 & 16 & 0 \\
\hline
\end{tabular}

Table 6. GLM model (Generalized Linear Model) explaining the influence of socioeconomic factors on the knowledge of plant and animal species.

\begin{tabular}{|c|c|c|c|c|}
\hline \multirow{2}{*}{ Categorias } & \multicolumn{4}{|c|}{ Valores } \\
\hline & Estimate & SE & $z$ value & $\operatorname{Pr}(>|z|)$ \\
\hline Intercept & 1.481336 & 0.304369 & 4.867 & $1.13 \mathrm{e}-06^{* * *}$ \\
\hline feminine gender & -0.695431 & 0.187764 & -3.704 & $0.000212^{* * *}$ \\
\hline elementary School & -0.116602 & 0.194398 & -0.600 & 0.548633 \\
\hline high school & 0.077422 & 0.227498 & 0.340 & 0.733618 \\
\hline higher education & 1.053116 & 0.298773 & 3.525 & $0.000424^{* * *}$ \\
\hline income between 1 and 2 minimum wage & 0.562099 & 0.130337 & 4.313 & $1.61 \mathrm{e}-05^{* * *}$ \\
\hline income over 2 minimum wage & 0.984102 & 0.228513 & 4.307 & $1.66 \mathrm{e}-05^{* * *}$ \\
\hline occupation agriculture & -0.390025 & 0.212143 & -1.839 & 0.065989 \\
\hline occupation art & 0.242561 & 0.116842 & 2.076 & $0.037897^{*}$ \\
\hline occupation home & 0.532396 & 0.187408 & 2.841 & $0.004499^{* *}$ \\
\hline christian religion & 0.009985 & 0.127426 & 0.078 & 0.937540 \\
\hline african religion & -0.163258 & 0.162157 & -1.007 & 0.314035 \\
\hline participation time in the cultural pratic & 0.004238 & 0.003803 & 1.114 & 0.265104 \\
\hline
\end{tabular}

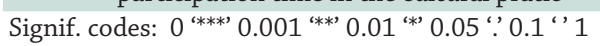

Table 7. Model GLM (Generalized Linear Model) explanatory of the influence of socioeconomic factors on the use of plant and animal species.

\begin{tabular}{|c|c|c|c|c|}
\hline \multirow{2}{*}{ Categorias } & \multicolumn{4}{|c|}{ Valores } \\
\hline & Estimate & SE & $z$ value & $\operatorname{Pr}(>|z|)$ \\
\hline Intercept & -2.375241 & 0.698820 & -3.399 & $0.000676^{* * *}$ \\
\hline feminine gender & -0.814315 & 0,459093 & -1.774 & 0.076105 \\
\hline elementary School & 0.980269 & 0,430320 & 2.278 & $0.022726^{*}$ \\
\hline high school & 1.613134 & 0,490424 & 3.289 & $0.001005^{* *}$ \\
\hline higher education & 2.310373 & 0,689965 & 3.349 & $0.000812^{* * *}$ \\
\hline income between 1 and 2 minimum wage & 0.466325 & 0,273467 & 1.705 & 0.088151 \\
\hline income over 2 minimum wage & 1.834948 & 0,454739 & 4.035 & $5.46 \mathrm{e}-05^{* * *}$ \\
\hline occupation agriculture & 0.793782 & 0,397938 & 1.995 & $0.046071^{*}$ \\
\hline occupation art & 0.753290 & 0,272753 & 2.762 & $0.005748^{* *}$ \\
\hline occupation home & 1.228780 & 0,447340 & 2.747 & $0.006017^{* *}$ \\
\hline christian religion & 0.351822 & 0,278945 & 1.261 & 0.207215 \\
\hline african religion & 0.537006 & 0,326345 & 1.646 & 0.099863 \\
\hline participation time in the cultural pratic & 0.019371 & 0,008699 & 2.227 & $0.025963^{*}$ \\
\hline
\end{tabular}

Signif. codes: 0 (***) $0.001^{(* *)} 0.01^{(*)} 0.05$ ‘’ 0.1 “'1 
In this study, the access of participants to forest fragments, for example, may justify the differences between knowledge and effective use of species. In the studied municipalities, the forest environments that provide the native species that are used in the practice of "Cavalo Marinho" occur in areas belonging to sugarcane mills, which restrict the population's access to resources. Another important point to highlight is the availability of natural resources in these forest fragments. Although our research did not measure the availability of species in the area, studies carried out in the region, such as Trindade et al. (2008), have demonstrated the critical state of conservation of these fragments due to the expansion of sugarcane cultivation.

Thus, we believe that, in order to meet their needs in this environmental context, the groups involved in the study are replacing some natural resources by exotic and domesticated species, or even by industrialized objects. The acquisition of these products, in terms of cost-benefit, becomes less expensive when compared to the use of artifacts produced with resources from local ecosystems. A recently observed practice has highlighted the substitution of locally manufactured musical instruments, such as rabeca, for similar industrialized instruments such as the violin (IPHAN 2014). The adoption of this practice may contribute to the loss of knowledge and practices associated with the use of natural resources (Cruz et al. 2013; Baker et al. 2014).

In the context studied, the loss of knowledge can affect mainly the species that are less used, since the knowledge about the resources that are effectively used has been widely diffused among the interviewees. The relationship between the greater knowledge of a species and its greater use has also been observed by other researchers. Ramos et al. (2008), for example, when investigating the use of natural resources used as biofuel in populations of the Northeastern Brazil, observed that the species with the highest frequency of citation of use were also the best known by the informants. According to the researchers, this scenario has important implications for biodiversity conservation, since these species are the subject of continuous exploration.

In relation to the biogeographic origin of the resources associated with the practice of "Cavalo Marinho", we highlight the contribution of the native flora in relation to the exotic. Although this cultural manifestation occurs in a region where access to forests is restricted, and that has been experiencing environmental transformations and loss of biodiversity, the population preserves the knowledge about the contribution of the native plant resources. However, when related to animal resources, knowledge and use of species are more closely associated with domestic animals, and the resources of animals used are restricted to elements such as horn, bladder, leather, horsehair, among others, which are obtained in slaughterhouses, markets and street markets of the region. The low incidence of the use of wild animals in this cultural practice may be a consequence of the environmental transformations that have occurred in the region over time, which have caused immediate impact on the availability of animals, and whose implications are directly reflected on the knowledge and use of these resources. Research carried out in the region has demonstrated the negative effect of Atlantic Forest degradation on animal populations in these forests (TelinoJúnior et al. 2005).

\section{Influence of socioeconomic factors on species knowledge and use}

Although women have been joining "Cavalo Marinho" over the years, they are still a minority (Souza 2010; Alcântara 2014). This may have reflected in the results of the studies that showed the men with as most knowledgeable of species of plants and animals when compared to the women in the groups studied, considering that the statistical analysis we used did not consider the sample discrepancy between men and women involved in this study.

The presence of women in "Cavalo Marinho" has been reported in the literature as a representation of the female figure interpreted by men dressed as women (Souza 2010; Alcântara 2014). This explains their recent contact with plants and animals employed in this cultural practice. The social role represented by men and women in "Cavalo Marinho" results in differences in the levels of knowledge about natural resources that are useful for the cultural expression. This evidence is similar to that found in other studies.

Camou-Guerrero et al. (2008), for example, have shown that the division of labor directs the knowledge of Rarámuri men and women in Mexico on some groups of plant species by gender. In this perspective, these researchers found that women in this social group know more plants for specific medical purposes, and they are responsible for harvesting these resources. On the other hand, the more widespread knowledge about plants among men is associated with the resources destined to the production of domestic products (spoons, axes and trays) and the construction of houses and fences, men having an important role in the work and harvesting of these plants. This trend has also been reported in other social-ecological systems (Ramos et al. 2008; Almeida et al. 2012; Beltrán-Rodríguez et al. 2014). However, researchers have demonstrated that it is not due to a global pattern, but to the effect of the social role played by gender in the social-ecological system (Albuquerque et al. 2011).

Regarding the use of resources to perpetuate the cultural expression, the informants with the highest levels of schooling and income exceled among those who use more resources in "Cavalo Marinho", differing from what has been reported for the use of natural resources in other socioecological systems (Holmes 2003; Medeiros et al. 2011). In rural areas, for example, the greater reliance on resources is associated with low levels of schooling and 
income, since people with this profile usually carry out low-paid activities, such as agriculture. It allows greater contact with natural resources. However, they rely on natural resources to supplement subsistence activities, such as the use of firewood.

Apparently, a direct expression between the level of schooling and the use of natural resources in the cultural practice is associated with an image of an educational profile of its members. This is because the participation of art students, music, theater and dance in "Cavalo Marinho" has been common, since it is a source of inspiration for their areas of expertise. In this sense, direct contact with people with artifacts made from natural resources obtained from local ecosystems, and the need to have them, may be contributing to a greater utilization of these resources.

Researchers have shown that the schooling factor is correlated with income, since people with higher incomes usually have higher levels of schooling (Medeiros et al. 2011). In this sense, the greater use of natural resources by people with this economic profile in "Cavalo Marinho" can be justified by the insertion of this recent audience. Another perspective that may justify this scenario would be the increase in income from the sale of artifacts used in "Cavalo Marinho", since some members usually make and provide musical instruments, clothing and other products to people of the region and the country. Although this justification could explain the influence of income on the use of resources in this cultural practice, our study would need to elaborate in detail the influence of this trade on levels of resource use.

The study also showed that people who develop activities related to arts, the countryside and home use more natural resources than people who provide general services. Activities that promote greater contact with nature, such as those developed in rural areas, for example, are known in the literature for directly influencing the use of natural resources (Medeiros et al. 2011; Campos et al. 2018). In our study, it seems that the greater contact with the objects derived from the resources of plants and animals in the cultural expression contributed to the greater use of natural resources by certain members of the groups, such as artists and people who work at home, since they dedicate more time to "Cavalo Marinho" than other informants.

The use of natural resources is also related to the time of participation of members in cultural expression. Informants with this profile were more experienced, because they had more contact with the natural resources and time to exchange information with other members of "Cavalo Marinho". In other socioecological systems, this accumulated experience has been associated with the age of the informants, since older people tend to accumulate more knowledge (SaynesVasquez et al. 2013; Beltrán-Rodríguez et al. 2014). However, the experience based on the age, in the context of our study, could suppress information of the interviewees, once the time of participation expresses better the contact of the members with the resources used in the cultural expression. For similar reasons, Campos et al. (2018) found that in the use of Syagrus coronata the harvesting experience was an important factor to guide the sustainable use of the species. The results of this study, although they did not evaluate the sustainable use of resources, suggest that the experience time in the group has a direct effect on the use of plants and animals that are useful for the practice.

\section{Final considerations}

The members of "Cavalo Marinho" groups develop different relationships with natural resources that are useful to the diffusion of this cultural practice. To understand the influence of socioeconomic variables on the knowledge dynamics and effective use of these resources among its members, we need to consider these different perspectives. In the present study, we found that the influence of gender and the accumulated experience, represented by the time of participation of the members in this cultural practice on the knowledge and effective use of natural resources, is similar to that reported for other social-ecological systems, such as those related to human subsistence. Conversely, the influence of factors such as schooling, occupation and income on these variables differ from what has been observed in these forms of appropriation of resources. As this study approaches cognitive aspects, it is necessary to increase researches that analyze the influence of socioeconomic factors on the dynamics of knowledge and use of natural resources in other cultural practices, so that the influence of these factors on these dynamics are better understood. This type of analysis is important because it can contribute to the conservation of biocultural heritage associated with these practices.

\section{Acknowledgements}

To the Foundation of Support to Science and Technology of Pernambuco (FACEPE), for the scholarship granted to the first author (Process no. - IBPG - 0611 - 2.05/14); to the University of Pernambuco (UPE), for the partnership in conducting the research; to the members to Laboratory of Ecology and Evolution of Social-Ecological Systems (LEA - UFPE), by academic support; to the informants of the groups Cavalo Marinho, for the inestimable support and permission to carry out the work.

\section{References}

Albuquerque UP. 2006. Re-examining hypotheses concerning the use and knowledge of medicinal plants: a study in the Caatinga vegetation of NE Brazil. Journal of Ethnobiology and Ethnomedicine. Journal of Ethnobiology and Ethnomedicine 2:30. doi: 10.1186/17464269-2-30

Albuquerque UP, Ramos MA, Lucena RFP, Alencar NL. 2014. Methods and techniques used to collect ethnobiological data. In: Albuquerque UP, 
Cunha LVFC, Lucena RFP, Alves RRN. (eds.) Methods and techniques in ethnobiology and ethnoecology. New York, Springer. p. 15 - 37.

Albuquerque UP, Soldati GT, Sieber SS, Ramos MA, Sá JC, Souza LC. 2011. The use of plants in the medical system of the Fulni-ô people (NE Brazil): A perspective on age and gender. Journal of Ethnopharmacology 133: 866-873.

Alcântara PHL. 2014. Na batida do baião: o cavalo-marinho no terreiroda família Teles em Condado-PE. MSc, Universidade Federal da Paraíba, João Pessoa.

Almeida CFCBR, Ramos MA, Silva RRV, et al. 2012. Intracultural variation in the knowledge of medicinal plants in an urban-rural community in the atlantic forest from Northeastern Brazil. Hindawi Publishing Corporation Evidence-Based Complementary and Alternative Medicine 2012(1): 679373. doi: 10.1155/2012/679373.

Alves RRN, Barbosa JAA, Santos SLDX, Souto WMS, Barboza RRD. 2011. Animal-based remedies as complementary medicines in the semiarid region of Northeastern Brazil. Hindawi Publishing Corporation Evidence-Based Complementary and Alternative Medicine 2011: 179876. doi: 10.1093/ecam/nep134.

Alves RRN, Rosa IL, Léo Neto NA, Voeks R. 2012. Animals for the Gods: Magical and religious faunal use and trade in Brazil. Human Ecology. 40: 751-780.

Baker LR, Olubode OS, Tanimola AA, Garshelis DL. 2014. Role of local culture, religion, and human attitudes in the conservation of sacred populations of a threatened 'pest' species. Biodiversity and Conservation. 23: 1895-1909.

Beltrán-Rodríguez L, Ortiz-Sánchez A, Mariano NA, Maldonado-Almanza B, Reyes-García V. 2014. Factors affecting ethnobotanical knowledge in a mestizo community of the Sierra de Huautla Biosphere Reserve, Mexico. Journal of Ethnobiology and Ethnomedicine 10: 2-18.

Benjamin R. 1999. Pequeno dicionário do Natal. Recife, Sociedade PróCultura.

Bhagwat SA, Ormsby AA, Rutte C. 2011. The role of religion in linking conservation and development: challenges and opportunities. Journal for the Study of Religion, Nature and Culture 5: 39-60.

Camou-Guerrero A, Reyes-García V, Martínez-Ramos M, Casas A. 2008. Knowledge and use value of plant species in a Rarámuri community: A gender perspective for conservation. Human Ecology 36: 259-272.

Campos JLA, Araújo EL, Gaoue OG, Albuquerque UP. 2018. How can local representations of changes of the avaliability in natural resouces assist in targenting conservation? Science of the Total Environment 629: 642-649.

Campos LZO, Albuquerque UP, Peroni N, Araújo EL. 2015. Do socioeconomic characteristics explain the knowledge and use of native food plants in semiarid environments in Northeastern Brazil? Journal of Arid Environments 115: 53-61.

Carneiro JM, Filho ML. 2010. Entre a cena e o som: uma abordagem do cavalo marinho pernambucano. Revista Modus 7: 31-44.

Cruz MP, Peroni N, Albuquerque UP. 2013. Knowledge, use and management of native wild edible plants from a seasonal dry forest (NE, Brazil). Journal of Ethnobiology and Ethnomedicine 9: 79. doi: 10.1186/17464269-9-79

Gavin MC, Mcacarter J, Mead A, et al. 2015. Defining biocultural approaches to conservation. Trends in Ecology \& Evolution 30: 140-145.

González AYV, Mejía C, Tapia H, Meléndez C. 2015. La fiesta xita: patrimonio biocultural mazahua de San Pedro el Alto, México. Culturales 4: 199-228.

Grillo MAF. 2011. Cavalo-marinho: um folguedo pernambucano. Revista Esboços 18: 138-152.

Holmes CM. 2003. Assessing the perceived utility of wood resources in a protected area of Western Tanzania. Biological Conservation 111: 179-189.

IBGE - Instituto Brasileiro de Geografia e Estatística. 2010. Censo 2010. http://www.ibge.gov.br/estadosat/perfil.php?sigla=pb\# . 11 Jun. 2017.

IPHAN - Instituto do Patrimônio Histórico e Artístico Nacional. 2014. Inventário nacional de referências culturais do Cavalo-Marinho. http:// portal.iphan.gov.br/uploads/ckfinder/arquivos/DOSSI\%C3\%8A_ CVMARINHO.pdp. 7 Feb. 2017.
Ladio AH, Lozada M. 2003. Comparison of wild edible plant diversity and foraging strategies in two aboriginal communities of northwestern Patagonia. Biodiversity and Conservation 12: 937-951.

López SR, Toledo BA, Galetto L. 2015. Use of wood resources in Central Argentina: A multivariate approach for the study of phytogeography and culture. Ethnobotany Research \& Applications 14: 381 - 392.

Lyon LM, Hardesty LH. 2014. Quantifying medicinal plant knowledge among non-specialist antanosy villagers in Southern Madagascar. Economic Botany 66: 1-11.

Medeiros PM, Almeida ALS, Silva TC, Albuquerque UP. 2011. Pressure indicators of wood resource use in an Atlantic Forest Area, Northeastern Brazil. Environmental Management 47: 410-424.

Mekbib F. 2009. Folksong based appraisal of bioecocultural heritage of sorghum (Sorghum bicolor (L.) Moench): A new approach in ethnobiology. Journal of Ethnobiology and Ethnomedicine 5: 19. doi: 10.1186/1746-4269-5-19

Nascimento VT, Lucena RFP, Maciel MIC, Albuquerque UP. 2013. Knowledge and use of wild food plants in areas of dry seasonal forests in Brazil. Ecology of Food and Nutrition 52: 317-343.

Nascimento ALB, Lozanoa A, Melo JG, Alves RRN, Albuquerque UP. 2016. Functional aspects of the use of plants and animals in local medical systems and their implications for resilience. Journal of Ethnopharmacology 194: 348-357.

Oliveira SRV. 1994. A rabeca na zona da mata norte de Pernambuco: levantamento e estudo. Monograph, Universidade Federal de Pernambuco, Recife.

Oliveira EJS. 2006. A roda do mundo gira: um olhar etnoecológico sobre a brincadeira do cavalo marinho estrela de ouro (Condado - Pernambuco). $\mathrm{PhD}$ Tesis, Universidade Federal da Bahia, Salvador.

Queiroz PO. 2014. Arte em forma de brincadeira, ou brincadeira em forma de arte? O cavalo-marinho e a dimensão criativa da vida. ACENO 1: 97-101.

R Development Core Team. R. 2018. A Language and environment for statistical computing. Vienna, R Foundation for Statistical Computing. http://www.R-project.org

Ramos MA, Medeirosa PM, Almeida ALS, Feliciano ALP, Albuquerque UP. 2008. Use and knowledge of fuelwood in an area of Caatinga vegetation in NE Brazil. Biomass and Bioenergy 32: 510-517.

Ramos MA, Lucena RFP, Albuquerque UP. 2015. What drives the knowledge and local uses of timber resources in human-altered landscapes in the semiarid region of northeast Brazil? International Journal of Sustainable Development \& World Ecology 22: 545-559.

Saynes-Vásquez A, Caballero J, Meave J, Chiang F. 2013. Cultural change and loss of ethnoecological knowledge among the Isthmus Zapotecs of Mexico. Journal of Ethnobiology and Ethnomedicine 9: 40. doi: 10.1186/1746-4269-9-40

Sharma UK, Pegu S. 2011. Ethnobotany of religious and supernatural beliefs of the Mising tribes of Assam with special reference to the 'Dobur Uie'. Journal of Ethnobiology and Ethnomedicine 7:16. doi: 10.1186/1746-4269-7-16

Silva AJR, Andrade LHC. 2006. Cultural significance of plants in communities located in the coastal forest zone of the state of Pernambuco, Brazil. Human Ecology 34(3). doi: 10.1007/s10745006-9026-0

Silva FS, Ramos MA, Hanazaki N, Albuquerque UP. 2011. Dynamics of traditional knowledge of medicinal plants in a rural community in the Brazilian semi-arid region. Revista Brasileira de Farmacognosia 21: 382-391.

Souto WMS, Barboza RRD, Fernandes-Ferreira H, et al. 2018. Zootherapeutic uses of wildmeat and associated products in the semiarid region of Brazil: general aspects and challenges for conservation. Journal of Ethnobiology and Ethnomedicine 14: 60. doi: 10.1186/s13002-018-0259-y

Souza RT. 2010. O Cavalo Marinho de Condado: a beleza da brincadeira e as representações das mulheres e das crianças (1960 - 1990). In: XIV Encontro Regional da ANPUH-RIO Memória e Patrimônio. ISBN 978-85-60979-08-0. Rio de Janeiro. Anais do XIV Encontro Regional de História da ANPUH-Rio: Memória e Patrimônio

Telino-Júnior WR, Dias MM, Júnior SMA, Lyra-Neves RM, Larrazábal MEL. 2005. Estrutura trófica da avifauna na Reserva Estadual de 
Gurjaú, Zona da Mata Sul, Pernambuco, Brasil. Revista Brasileira de Zoologia 22: 962-973.

Torres-Avilez W, Medeiros PM, Albuquerque UP. 2016. Effect of gender on the knowledge of medicinal plants: Systematic review and meta-analysis. Hindawi Publishing Corporation Evidence-Based Complementary and Alternative Medicine 2016: 6592363. doi: $10.1155 / 2016 / 6592363$
Trindade MB, Lins-e-Silva ACB, Silva HP, Figueira SB, Schessl M. 2008. Fragmentation of the Atlantic rainforest in the northern coastal region of Pernambuco, Brazil: recent changes and implications for conservation. Bioremediation, Biodiversity and Bioavailability 2: 5-13.

Voeks RA, Leony A. 2004. Forgetting the forest: Assessing medicinal plant erosion in Eastern Brazil. Economic Botany 58: 294-306. 